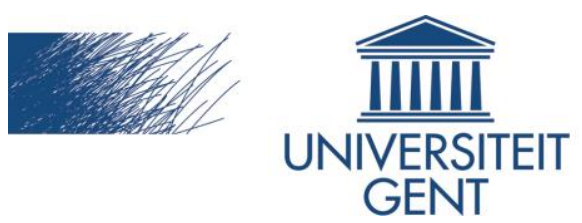

biblio.ugent.be

The UGent Institutional Repository is the electronic archiving and dissemination platform for all UGent research publications. Ghent University has implemented a mandate stipulating that all academic publications of UGent researchers should be deposited and archived in this repository. Except for items where current copyright restrictions apply, these papers are available in Open Access.

This item is the archived peer-reviewed author-version of:

The argumentation in workplace accident trials. The case of the civil court of Mons (1870-1904)

Bruno Debaenst

In: Clio@Themis, numéro 8, no pages, 2015.

http://www.cliothemis.com/The-argumentation-in-workplace

To refer to or to cite this work, please use the citation to the published version:

B. DEBAENST, The argumentation in workplace accident trials. The case of the civil court of Mons (1870-1904), Clio@Themis 2015, http://www.cliothemis.com/The-argumentation-in-workplace 


\section{The argumentation in workplace accident trials. The case of the civil court of Mons (1870-1904)}

Résumé : À la fin du dix-neuvième siècle, les procès d'accident du travail se multiplient en Belgique, comme dans les autres pays européens. Ces procès ont un caractère hybride, mêlant argumentation industrielle et juridique. L'article analyse cette argumentation spécifique via l'étude de 293 procédures ayant eu lieu devant le tribunal civil de Mons entre 1870 à 1904.

Mots clés : Belgique, responsabilité, accidents du travail, argumentation, tribunal civil

Abstract : At the end of the nineteenth century, workplace accident trials increased significantly in number in Belgium and in other European countries. These cases are interesting, as they have a hybrid character, with a unique blend of industrial and legal argumentation. The article focuses on 293 cases from the civil court of Mons, from the period 1870 till 1904, in order to analyze this specific argumentation.

Key words : Belgium, liability law, workplace accidents, argumentation, civil court

\section{Introduction}

1. At the end of the nineteenth century, workplace accidents became a « hot topic » in the Western industrialized world. For instance, workplace accident trials increased significantly in number in Belgium and other European countries [1]. This led to a rise in jurisprudence, with studied from lawyers such as Sainctelette [2] and Pirmez [3] in Belgium and Sauzet [4], Saleilles [5] and Josserand [6] in France, who published extensively on workplace accident liability law. As a result, in 1898 in France and in 1903 in Belgium, workplace accidents received an own system of indemnities, through insurances. These workplace accidents insurances can be considered as the trailblazers of the modern welfare state [7]. With the introduction of the new insurance based legislation, the flourishing extra-contractual liability law cases regarding workplace accidents disappeared abruptly. Nevertheless, these cases are very interesting, as they have a hybrid character, with a unique blend of industrial and legal argumentation. In this contribution, I will analyze 293 workplace accident trials that I tracked down in the archives of the civil court of Mons, an industrial district in the South of Belgium, dating from the period 1870-1904 [8]. I will begin by analyzing the specific nature of the argumentation in these workplace accident trials. Here, I will investigate the application of various articles of the Civil Code. For example, article 1382 reveals a number of workplace accident specific categories of fault. Further, a number of workplace accident cases applied articles 1384, 1385 and 1386. In addition to these articles, one can find traces of the application of the contractual liability theory of Charles-Xavier Sainctelette. The second part of this paper will focus on the way parties delivered their arguments to prove or refute the plaintiff's claims. Three distinct tools will be studied here : criminal investigations, expert's reports and witness testimonies.

\section{The hybrid argumentation of workplace accident trials}


2. Workplace accidents are a specific category of accidents because they happen in a specific location - the workplace - within a specific relationship - the labor relation - between specific actors - employees and employers, while doing a specific activity - labor. Legally however, in the nineteenth century, workplace accidents were not considered distinct from other unfortunate events such as traffic or domestic accidents. Workplace accident victims, who wanted to get compensated, needed to sue their employer (or a third person), applying the general rules of non-contractual liability (the articles 1382-1386 of Belgium's civil code).

\section{A. Art. 1382 of the Civil Code}

3. Article 1382 of the Civil Code, containing the general rule of fault liability, was invoked most frequently. Here, the plaintiff had to deliver the difficult proof that the defendant (typically the employer) had committed a fault or neglect, which caused the accident [9]. When analyzing the judgments, a number of categories of workplace accident specific faults can be traced.

4. A first «tort» was the use of deficient and dangerous machinery. Louis Marin was on 22 October 1897 victim of an accident in the military bakery of Mons, when his hand was chopped off by an automatic kneader [10]. The judges considered it a very dangerous machine, as the circulating cursor easily could hurt an inattentive worker. Moreover, the accident could have been avoided by installing a protective hood. In another case, Edgard Lheureux, a joiner mutilated by a broken planning machine, filed a lawsuit against his employer, the Société en nom collectif M. Wrede et Jungbluth [11]. The court decided that the latter was at fault because he let Lheureux work with the defective machine without any form of protection against its knives [12].

5. A second category is accidents allegedly caused by a defective operation. In the mines for example, defective shoring could cause collapses. The relatives of Auguste Tachegnion, who was killed in such a mining accident on 13 June 1897, tried to prove in court that the collapse was caused by the use of defective wooden beams [13]. In the case of mining engineer Verniory [14], the judges stated that the defendant was only liable for the accident if the falling stone could have been foreseen and if the defendant would have neglected to take the necessary precautions against this danger [15]. Following his workplace accident of 16 December 1896, miner Mansy claimed that a lack of supervision had caused the collapse of the mineshaft [16]. Other examples of alleged defective operations can be found in railroad accident cases. For instance, in the night of 22 to 23 February 1898, Emile Leleux was victim of an accident when he was caught between two wagons of the Belgian state railroads [17]. In court, he claimed that his employer was to be blamed for his accident : he had to work in almost complete darkness and on the spot of the accident, reparation works were happening. The court followed his reasoning and condemned the Belgian state to pay damages.

6. A third category of argumentation invoked in workplace accident cases concerned an alleged defective labor organization («vicieuse organisation du travail » [18], «mauvaise organization du travail » [19], «un vice d'organisation » [20], « une organisation défectueuse du travail » [21]). This broad concept covered many different situations, all having in common that the production process, or part of it, was poorly organized by the employer. This argument was often used for accidents that had happened during the dangerous underground transport in the mines [22]. 
7. A fourth often invoked argument was the deployment of 'defective' workers, who were not suitable for their entrusted tasks. Désiré Legrand for example described himself as an inexperienced worker («un ouvrier inexpérimenté ») [23]. Trained as painter, he had no experience in the dangerous work he had to perform for his new employer, industrialist Lemaire from Mons. Apparently, Lemaire frequently hired inexperienced workers [24].

8. One distinct subcategory of « defective » workers was children. In the nineteenth century, child labor was a widespread phenomenon [25] and therefore, not surprisingly, many children were victims of workplace accidents. Thirteen year old Alphonse Vertenoeil, for example, was crushed to death on 11 June 1888 by a rock that had fallen from the ceiling [26]. The judges ruled that there was no link between Alphonse's young age and the accident, declaring this argument as irrelevant [27]. This was also the case in the civil trial dealing with the deadly accident of Hilaire Dubois on 6 February 1890 : in a judgment dated on 29 June 1893 the judges wrote that the young age of Dubois had no causal link with the accident. After all, the fire explosion not only killed Dubois, but also adult miners [28]. Interestingly, a general rule of conduct towards children working in industrial enterprises was formulated in this judgment : children needed to be more supervised than other workers, in order to protect them against their own imprudence or against the accidents that could be the result of their inexperience [29]. Besides, it was a general rule of conduct that employers had to protect their workers against their own imprudence, only, this rule of conduct was much stricter in the case of minors [30].

9. In the night of 17 August 1881, fourteen year old Emile Dufrasne was crushed by a runaway coal wagon [31]. According to the plaintiff, such a dangerous job was normally trusted to adults, especially during the night. A similar argumentation was used in the civil trial following the workplace accident of seventeen year old Alexandre-Joseph Haneuse, who died on 10 March 1883 while putting a railway car back on the tracks - normally an adult fulfilled this task [32].

10. An often reoccurring argument was that minors did not have the same physical strength or experience as adult workers. Sixteen year old Emilia Lansman, for example, allegedly had to perform a dangerous and exhausting service, that was usual confined to an older worker [33]. The defendant replied that Emilia had done the job more than a month without complaining and that the work was not as tiring as claimed. Another case dealt with the workplace accident of Henri Lefrancq, who had to bring oil lamps to the workers [펴]. On 12 august 1897, one miner was absent and Henri replaced him, which led to an accident. According to the plaintiff, the company had committed an error by entrusting that job to a thirteen year old, who was not familiar with it and who did not have sufficient physical strength. In yet another case, on 26 April 1891, at six o'clock in the morning, François Léon Crombois died when his head was crushed between a wagon and a pillar [35]. His father claimed that the assigned work was too dangerous for a child younger than fourteen. In a judgment dated on 28 April 1893 the Mons judges proved him right [즈. The installation of the defendant was dangerous for any worker and especially for a child, who did not have the strength nor the experience of an adult [37]. Two years earlier, thirteen year old Charles Derveau had died in similar circumstances [38]. Apparently, Derveau had received a task, which was normally given to a seventeen or eighteen year old worker, without any explanation or training ! After describing the dangerous working conditions, the court concluded that the defending company had made an error which made it liable for the accident. The judges did admit that Derveau himself had been imprudent, but, given his age, this was expected. 
11. Yet another category of argumentation related to the workplace regulations (« règlements d'atelier »), which made it easier for the plaintiffs to prove that a mistake had been made, or, the other way round, that the victim himself had been imprudent by acting against the rules of the workplace. When Emmanuël Caucheteur was working in the fourth pit, he was in violation with article 13 of the workplace regulation, because he did not have permission to be there [39]. In their judgment of 29 July 1899, the judges even spoke of an incredible imprudence of the victim, who had ignored the repeated warnings of his colleagues. In the trial of Jules Defrasne against the Société anonyme des charbonnages d'Hornu et Wasmes, a violation of the workplace regulation was brought up, as Defrasne had been walking on a tilt («plan incliné »), which was forbidden by article 13, C of that regulation [40].

\section{B. The articles 1384, 1385 and 1385 of the Civil Code}

12. A few plaintiffs tried to invoke article 1384, first paragraph of the Civil Code [41]. One of them was Félicien Née. His minor son with the same name had been severely wounded when a number of empty wagons had tumbled. According to Née, the accident was caused by a malfunctioning brake [42]. He believed the company responsible for the accident, because it was the owner of the brake. The judges reminded him that Belgian case law was clear : defective objects did not automatically imply liability for their owners [43]. Only when the plaintiff could prove that the accident was the result of neglect by the owner (= general application of article 1382 Civil Code), the latter was liable [44]. Only in 1904, the Court of Cassation would change this view [45].

13. More interesting is the application of article 1384, third paragraph of the Civil Code, on liability of masters and employers for the damage caused by their servants and employees [46]. It comes as no surprise that this clause was used frequently in the context of workplace accidents. Moreover, in reality, this clause was more interesting to the plaintiffs than article 1382 of the Civil Code. To start with, the employer was generally wealthy, in contrast to the often impecunious co-worker/perpetrator. Moreover, the plaintiffs could benefit from the fault presumption of the employer, resulting from negligence or lack of surveillance [47].

14. The application of this provision on workplace accidents also offers a glimpse of the underlying work relations and their legal interpretation at that moment. After all, the Civil Code did not offer many provisions regarding work relations, only a few articles on the contract of rent of work («contrat de louage d'ouvrage ») and the contract of rent of services («contrat de louage de service $»)$.

15. When the plaintiff used article 1384, third paragraph of the Civil Code, the defendant sometimes tried to escape liability by arguing that he was not the master or employer of the worker who had caused the work accident. In the trial of Valérie Lourette against the Société du charbonnage de La Louvière et la Paix for example, the plaintiff argued that her deceased husband Augustin Terrasse was a simple miner in the service of the company [48]. The latter denied this and claimed Terrasse was part of a group of workers who worked on a contractual basis. Moreover, the company had clearly communicated the contractual provisions to the leader of the group ( «chef des bandes d'ouvriers entrepreneur »). One of these provisions contained an exemption clause, stating that the «entrepreneurs » would not start a civil trial against the company [49].

16. A task which usually was similarly outsourced, was the digging of mine pits, a highly technical and dangerous work. The Société anonyme des charbonnages de Houssu had trusted 
the deepening of its eighth pit to a certain Vincent Mabrée [50]. It seems to have been a substantial contract, with a value of 40.000 francs. In return, Mabrée promised to deepen the pit 200 more meters. On 28 January 1889, during that work, an accident occurred and the 27 year old son of Mabrée perished. His widow, Sidonie Flasse, filed a case against the company in her own name and in that of her eighteen months old daughter Laure Mabrée. During the trial, the father of the deceased claimed that he was a simple digger («ouvrier puisatier ») and the only subsidiary was the head of a workers brigade ( chef de brigade d'autres ouvriers »). The contract he had signed with the Société was similar to other contracts signed between mining companies and diggers. Mabrée worked alongside the other workers and received the same wage as his co-workers for his personal share in the work, based on the number of working days, the progress they achieved and a fix price. This way he earned 5 till 6 francs a day in average. The only difference was that he received a supplementary bonus of 5 francs for each meter, for the recruiting of the workers and being their chef [51].

17. On 24 April 1891, the court of Mons had to deal with the legal status of the relationship between mason Adhémar Dubois and the Société anonyme du Levant de Flénu, following the accident of Julien Wanquier. During the installation of a steam boiler, the latter's hand was crushed. The judges argued that the boiler's installation had been outsourced to Dubois, who had conducted the task with a number of workers he had hired, supervised and paid. In addition, the company had no direct authority over Dubois. In this manner, the principle of article 1384, third paragraph of the Civil Code did not apply on the company [52]. In 19001901, a similar trial dealt with the accident of Jules Barbieux on 4 August 1899 [53]. Again it was questioned if «entrepreneur » Mest could be seen as an appointee of the company, in the sense of article 1384 of the Civil Code. The court stated that authority was a necessary element [54]. Since Mest exclusively had exercised the management and supervision on the workplace, Barbieux could not be seen as an appointee of the company. In these cases, the workers were clearly external experts, who came to perform a specific and technical task.

18. When the workers were « proper» miners, the Mons court was more compliant. On 13 September 1882 Casimir Blase succumbed in a pit of the Société des charbonnages du Grand Buisson in Hornu [55]. The latter argued that it did not employ the victim. In a judgment of 14 November 1885, the judges rejected this argumentation. It was not because Blase had worked for an entrepreneur that the company automatically was freed from liability for accidents in its mine. After all, according to the judges, this entrepreneur was only an intermediary for the payment of wages and a mean to facilitate the organization of the exploitation [56]. Clearly, the company was the actual employer : it preserved their workbooks, it could fine them and, last but not least, the workers were affiliated with the welfare fund of the company.

19. Article 1385 of the Civil Code, which contains the liability for damages inflicted by animals, was used in a number of cases as well [57]. At that time, many animals were used in the industry as traction. Most accidents happened with horses, for example, in the underground transport in the mines. Jules Devos was, on 15 July 1885, a victim of an accident when a horse of the Société anonyme des charbonnages de La Louvière, La Paix et SaintVaast caused a collapse of the mineshaft [58]. By judgment of 23 April 1891, the latter was condemned to pay 5.000 francs to the former [59].

20. Finally, article 1386 of the Civil Code was also applied a few times [60]. Henri Brulard, for example, was killed in a pit of the Charbonnage de l'Escouffiaux (property of the Société des charbonnages belges), when he was hit by a falling brick [61]. His widow invoked article 1386 of the Civil Code in order to claim that the brick had fallen because of poor masonry. 
The court rejected this simple argumentation. At the very least, the plaintiff had to prove that there were no defects in maintenance or construction that would have led to the accident.

\section{A dissonant note : Sainctelette and his contractual liability argument}

21. All the aforementioned cases dealt with the application of non-contractual liability in workplace accident cases. Interestingly, a number of judgments in the period 1885-1888 also contain traces of contractual liability argumentation. The source of inspiration here was the 1884 theory by Charles-Xavier Sainctelette [62]. This Belgian liberal politician and lawyer started from the 'summa distinctio' between contractual and non-contractual obligations. He believed that in many contracts, warrants were used to ensure a correct execution. Therefore, this must be a general characteristic of all contracts. Subsequently, Sainctelette claimed that the work contract also contained such a warrant : employers had to make sure their workers could work in safe conditions, in other words, they had to warrant the safety of their workers. When a workplace accident occurred, the employer had to prove that he had taken all necessary preventive measures. In reality, this new theory implied a reversal of proof, as the heavy burden of proof shifted from the worker to the employer.

22. The first, and most exhaustive judgment in Mons acting on this new theory can be found in the case of Casimir Blasé, who had been victim of a lethal accident on 13 September 1882 in a mine of the Société des charbonnages du Grand Buisson in Hornu [63]. In the citation, his father simply stated that the company had employed his son, and, therefore, it had to pay for all the damages caused by the accidental loss of his son [64]. Obviously, Blasé senior was applying Sainctelette's new theory. In a judgment of 14 November 1885, the court of Mons responded to this new argumentation. First, the judges wrote that the underlying contract ('louage d'ouvrage ou de service') did not contain any provision regarding a safeguarding duty for the employer [ $[\underline{65}$ ]. The only obligations in that contract were related to labor and wage. The judges did admit that the employer had an obligation to protect his workers against danger, but this was not part of the underlying contract as it was an application of the general principles of fault liability. Judging otherwise would be an intrusion on the principle of article 1163 Civil Code, stating that the judges have to take into account the common will of both parties when they entered into the contract. Also, the legislator never mentioned any contractual safety obligation for the employer. If Casimir Blasé wanted to get compensated for his losses, he had to prove a fault of the company or its employees. In the following months and years, the judges had to answer several times to Sainctelette's contractual liability argument, but they remained firm and rejected it repeatedly [66]. Only with the introduction of the 1903 Workplace Accident Act, did the payment of compensation become grounded on a contractual basis [67].

\section{Three distinct ways of delivering proof in workplace accident trials}

23. Most lawyers (judges, attorneys) during the nineteenth century were entirely unfamiliar with the workplace. In fact, there was no such thing as 'the' workplace, as the industry was characterized by numerous sectors, each with its own organization, scale, complexity, etc. In Mons for example, charcoal was the dominant economic activity, but the district had also many quarries, factories (metal, chemistry, glass, food, etc.), construction firms, railroads, agriculture, etc. Even within one industry, there were many differences. Mining for example was a complex enterprise, with a variety of specialist workers performing their relative tasks. 
24. This raises the fundamental question of how the judges in Mons could judge professionally these workplace accident cases. The problem is closely related to plaintiff's difficult task to deliver the necessary proof to obtain compensation from the defendant. It turns out that parties had three kinds of evidence to back up their argumentation : criminal investigations, judicial experts and testimonies.

\section{A. Criminal investigations}

25. In many cases, criminal investigations proceeded the civil trial [요. After all, workplace accidents caused physical damage to workers, varying from small injuries, inflicting temporary disability, to serious injuries with lethal consequences, punishable by the articles 418-420 of the Criminal Code [69]. The criminal investigations could lead to a condemnation by the criminal court. When this was the case, it was relatively easy to obtain compensation from the civil court. For example, on 28 July 1874 an appointee of the Société anonyme charbonnière des Produits was condemned by the criminal court of Mons for the death of Jean Baptiste Lecomte during the catastrophe of 1 March 1872. Consequently, his parents, Emmanuel Lecomte and Félicité Paturiaux, started a civil trial to obtain compensation. In a judgment of 3 July 1875, the judges wrote that the defendant did not deny its civil liability ; only the amount of compensation requested by the plaintiffs was contested. On 6 July 1876 they condemned the defendant to pay 2.585,84 francs to Jean-Baptiste's parents.

26. Most criminal investigations did not lead to a conviction, but even then, the documents of these investigations could be useful for the civil trial : in 92 of the 293 studied criminal files, traces can be found of attorneys asking permission to view and to copy the criminal documents. Sometimes the attorney wanted to study the criminal file to see if there were sufficient incriminating elements to start a civil trial [70]. Marie Desiméon, for example, lost her eye in a workplace accident. This event had been investigated by the criminal investigators, but was dismissed. Her attorney, Victor Hanotiau, nevertheless asked permission to study the criminal file because the absence of criminal liability did not exclude civil liability [71]. In another case, Georges Leclercq wrote on 22 December 1899 that the study of the criminal file would help him to see if a demand for damages would be just [72].

27. Others already had started a civil trial when they asked permission to the public prosecutor to study the criminal file. Jean Van Langenhove for example wrote on 23 February 1900 a letter to the public prosecutor as attorney of the widow of Emile Méhaulder, who had died on August 1899 in Ecaussines d'Enghien. In this letter, he claimed that the use of the elements of the criminal file was indispensable to be able to defend the interests of his client [73]. After all, the criminal file could contain information that could be used as argumentation in court. Mostly, it was the plaintiff's attorney who asked permission, but in a number of cases, the criminal file also contains similar letters from the attorneys of the defendants [74]. In this way, they could verify if the demands of the plaintiffs were justified [75]. The request had to be sent to the public prosecutor in Brussels (the procureur-général to be precise). Inexperienced trainee attorney Charles Dawant mistakenly had asked permission to the public prosecutor in Mons, who had referred him to the public prosecutor in Brussels [76]. The latter generally authorized the study and copy of the criminal file without any problems. In fact, his administration had a standard authorization letter at its disposal. Only in a few specific cases was authorization denied. For example, on 6 December 1900, the public prosecutor wrote a letter to attorney Edmond Preumont refusing authorization, as the criminal investigations had not been finished yet [77]. 
28. Giving authorization to study the criminal investigations was one thing, giving permission to use the documents as element of proof in the civil trial was another. In a few specific cases, the judges refused this. For example, in the civil trial following the workplace accident of Louis Vincent Bracqueniez on 15 March 1874, the judges concluded that the defending society had not been included in the criminal investigations and so, the documents of the criminal and administrative investigations could not be used in the civil trial against this society [78]. Mostly however, the judges accepted without any problems the use of the criminal file as element of proof in the civil trial. In 1896, they explained that the plaintiff could deliver the evidence of fault or neglect of the defendant by all serious, clear and corresponding presumptions and in this way, the civil court could, without problem, use the criminal investigations to get a better understanding of the circumstances of the accident [79]. A special case was the workplace accident that Louis Marin had suffered in the military bakery of Mons on 22 October 1897 . Here, the military prosecutor had conducted the criminal investigations [80]. During the civil trial, the attorney of the defendant (= the minister of war as representative of the Belgian State) tried to argue that the plaintiff could not use the elements of these investigations. The court did not accept this argument, as the oath and composition of the investigation commission gave all the necessary guarantees of impartiality and sincerity.

\section{B. Expert's reports}

29. Often, during the criminal or administrative investigations, one or more experts had been assigned to give their expert opinion. Similarly, the civil judges could also order the appointment of a judicial expert. Sometimes there was a link between both. In the trial of miner Valentin Waroquier, for example, the court did not think it was necessary to appoint judicial experts, since the administrative and criminal investigation had already revealed the exact circumstances of the accident [81]. In a judgment of 13 January 1894, the court stated that the accident had been the object of both an administrative and a criminal investigation [82]. The plaintiff also had used these documents in the debates. This had allowed the court to determine that the accident was caused by the formation of ice in the elevator. Still, certain contradictions in the criminal investigations necessitated the appointment of judicial experts in the civil trial [83].

30. Victor Debaise, a carpenter's servant, mutilated his hand on 2 July 1890 in the workplace of Edouard Houlet, when putting his left hand in a planing machine [84]. The plaintiff claimed that the accident was due to defective machinery. In reaction, the court appointed three specialists to investigate if the machinery was dangerous [85]. The expertise concluded that the machinery was not defective and that Houlet had been imprudent.

31. On 28 December 1891 several workers died in a firedamp explosion in the mine of the Société anonyme de la Louvière, la Paix et Saint Vaast. In the wake of this disaster, two civil trials were initiated. In both cases the court ordered three mining engineers to investigate the circumstances of the accident [86]. On 15 July 1898 Félicien Née died because of a workplace accident in the underground transport in the first pit of the Charbonnage du Grand Buisson. The main question was whether the transport installation was defective or not. In his report of 22-24 January 1899, chief mining engineer Jules Dejaer concluded that the working conditions of the young miner were extremely dangerous [ [87]. The court decided to appoint three specialists to investigate whether the accident was due to negligence, fault or the use of a defective installation and if the accident could have been avoided under normal circumstances. In their report of 7 February 1903, the experts confirmed that the accident was 
due to the use of defective material. Strangely enough, the court decided that there was no causality between the defective material and the accident and rejected the demand.

32. One special category was the medical investigations. Here, the judges asked physicians to investigate the victim and to report about his injuries. Sometimes, the defendant claimed that there were no injuries, or that the injuries had disappeared. The Sociéte anonyme des Charbonnages du Rieu du Coeur et de la Boule for example claimed that its former employee Luciani Descamps had healed completely and could go back to work. It asked for a medical investigation that could bring clarification in this case [88]. In two trials of train drivers against the Belgian state, the latter recognized its liability but asked the appointment of medical experts [89]. The court granted this request and stipulated that it wanted the following four questions answered : 1) what were and would be the consequences of the accident ;2) whether these consequences affected his capacity to work ; 3) whether this condition was final or whether there were chances for improvement or healing in the future ; 4) whether the consequences of the accident resulted in heavy pains and a shortening of the life expectancy? [90] In other cases, the defendant acknowledged the damage and his liability, but contested the amount of the damages. Virgile Thauvoye, for example, asked for a staggering 20.000 francs for his accident in the pit of the Société anonyme des charbonnages des Produits [91]. To settle the case, the court ordered a medical expertise [92].

33. The judges were also interested in the severity of the injury, both in the past as in the future. Was the victim only temporary injured or would he be incapacitated for life ? [93] And if he would be able to work, could he do the same job or would he had to find another job ? In the case of Arthur Mahieu the physicians concluded that he only had $60 \%$ of his working abilities. He would never work as a roofer again, but an occupation as joiner was still possible [94]. These questions were all relevant for the amount of the damages. Due to a mining accident, François Blairon's eye was severely injured [95]. The ruling of 24 July 1896 awarded 3.000 francs provisionally and appointed three physicians as medical experts. They concluded that Blairon's eye was completely and irreversibly lost [96]. Moreover, the loss of his eye caused a heavy and constant pain that had undermined his health condition. Also, his remaining eye showed indications of irritation and a diminished eye sight and suffered constant threat to be affected by the dead eye. The only way to avoid this, was surgically removing the lost eye. Consequently, they concluded that Blairon had lost $75 \%$ of his productive value [97].

\section{Testimonies}

34. Parties could also request for testimonies under oath by witnesses or other people closely involved in the accident. Sometimes this was refused by the civil judges because they considered that testimonies would have no added value. For example, in the workplace accident trial of Théodore Demulders, the judges stated that the public prosecutor already had heard all the witnesses the plaintiff wanted to call to the stand [98]. Therefore, the judges considered the requested witness interrogation unnecessary and vexatious. Mostly however, the judges agreed, in which case they made an interlocutory judgment with a list of arguments that had to be proven, or refuted, through hearings. In the judgment books of Mons, many examples of these interlocutory judgments can be found.

35. All these interlocutory judgments contain a list of arguments raised by the plaintiff and often also a list with counter arguments offered by the defendant. One random example can illustrate this. In the trial of Arsène Maes against the Société anonyme des charbonnages de 
Bray, Maurage et Boussoit, the court of Mons made an interlocutory judgment on 21 November 1896. The judges stated that plaintiff articulated a series of facts, which pointed in the direction of a number of mistakes that allegedly would have led to the accident. The plaintiff first wanted to prove that he was working temporary as a mechanic for the defendant, when on 16 February 1895 his right hand got caught in a gearing, which necessitated its amputation afterwards. Secondly, he wanted to prove that the mutilating gearing was placed at only one meter from the surface. Thirdly, at the moment of the accident, the gearing was not covered ; this was done immediately after the accident. Fourthly, the accident happened when Maes wanted to put the belt back on for the third time. To do so, he slowed the machine down (instead of stopping it) and approached the pulley. At that moment, he slipped on the oily floor, hit his hand against the column and two gears caught the sleeves of his shirt. Fifthly and finally, Arsène Maes wanted to prove the following facts : he was 51 years old, he was father of three children, he earned 3,30 francs a day at the moment of the accident and he was totally incapacitated since the accident.

36. The defendant contested these facts and offered to prove the following four counter arguments. Firstly, the plaintiff repaired the triage usually in absence of the mechanic and therefore he knew the installation perfectly. Secondly, the sprocket was situated in a place where the workers had no easy access. Therefore, there was no improvidence not to cover it. Thirdly, there was no oil on the floor, as the machines were greased with thick oil, using closed vases. Finally, the accident was due to the imprudence of the victim. He attempted to replace the belt, whereas normally someone else performed this task.

37. After having heard the witnesses, the court reached its verdict on 7 May 1897. To start with, the testimonies affirmed there was not enough oil or grease on the floor to constitute any danger for the workers. Further, the gearing was situated in a separate corner of the room, where only the mechanic or his helper had access. In these circumstances, not covering the gearing with a protective device did not constitute imprudence, especially because there was no need to be there when the machine was working. According to the judges, the real cause of the accident was to be found in the improvidence of the victim himself, who had tried to replace the belt while the machine was still working, 'contraire à l'ordre établi, et malgré la defense qui lui en avait été faite'. Not surprisingly, the judges rejected Arsène Maes' plaint.

38. The example above illustrates the argumentation strategies of both parties. If the witnesses would have confirmed plaintiff's argumentation, there would have been sufficient reason to condemn the defendant. After all, it would have been a mistake to use machinery with moving parts that were not covered by protecting devices (= 'dangerous machinery'). Also, the alleged presence of an oily floor would have constituted a clear danger, which could not be tolerated (= 'defective organization'). However, in this case the defendant successfully refuted the allegations : the machine was situated in a remote corner, only accessible to specialists and the floor was apparently not oily. The only reason the accident had happened was because of the victim's own imprudence. However, even more than one hundred years later, it is obvious that the judges easily could have judged differently. To start with, the fact that the machinery was to be found in a remote corner of the workplace, does not necessarily justify the absence of a protective devise. Moreover, there seems to be some contradiction between the first and fourth argument of the defendant : the first argument states that the plaintiff regularly repaired the installation and that he replaced the mechanic in case of absence ; therefore, he was perfectly aware of the installation [99], whereas the fourth argument states that replacing the belt was someone else's task and so the accident was due to 
the imprudence of the victim... [100]. It seems that the employer tacitly accepted that from time to time Maes repaired the machine in absence of the mechanic...

39. Obviously, the judges had to make a subjective consideration of the argumentation offered by the parties and in the above case, they decided in favor of the employer. It turns out that the judges in Mons, generally speaking, were not very indulgent towards the plaintiffs in workplace accident cases. In half of the studied cases, the claim was rejected (5\% inadmissible and $45 \%$ unfounded). In $23 \%$ of the cases, no final judgment could be found, most likely because the plaintiff just had given up. Out of the 293 studied workplace accident trials, only 80 were successful (27\%). Moreover, in 25 out of these 80 successful cases, the plaintiff and the defendant had made a settlement during the trial...

\section{Conclusion}

40. The argumentation in workplace accident liability cases had a hybrid character. On the one hand, the plaintiffs applied the general rules of (non-) contractual liability, but on the other hand, the specific context of the accident created new categories of argumentation, typical for workplace accidents, such as defective machinery, poor work organization, unfit workers, etc. The civil court judges, who were generally not familiar with workplace accidents, had several tools at their disposal to get a better understanding of the case. They could appoint judicial experts, organize hearings or allow the documents of the criminal investigations to be added to the trial. Although these tools helped the plaintiffs to deliver the difficult proof of their argumentation, it turns out that only a minority of the workplace accident cases actually led to a condemnation of the defendant.

\section{$\underline{\text { Haut de page }}$}

\section{Notes}

[1] B. Debaenst, « The relativity of turning points : labour accident legislation and its “hidden”' prelude », S. Hornyák, B. Juhász, K. Korsósné Delacasse and Z. Peres (ed.), Turning points and breaklines, München, 2009, p. 207-213 ; E. F. D. Engelhard, «Shifts of work-related injury compensation. Background analysis : the concurrence of compensation schemes », S. Klosse and T. Hartlief (ed.), Shifts in compensation work-related injuries and diseases, Vienna, 2007, p. 9-82 ; P. Bartrip and S. Burman, The wounded soldiers of industry : industrial compensation policy, 1833-1897, Oxford, 1983 ; P. Fishback and S. Kantor, A prelude to the welfare state. The origins of workers' compensation, Chicago, 2000 ; J. F. Witt, The accidental republic : crippled workingmen, destitute widows, and the remaking of American law, Cambridge, 2004 ; J. M. Kleeberg, « From strict liability to workers' compensation : the Prussian railroad law, the German liability act, and the introduction of Bismarck's accident insurance in Germany, 1838-1884 », Journal of International Law and Politics, 2003, p. 53-132.

[2] C. Sainctelette, De la responsabilité et de la garantie (accidents de transport et de travail), Brussels, Bruylant, 1884.

[3] E. Pirmez, De la responsabilité. Projet de révision des articles 1382 à 1386 du Code civil, Brussels, Hayez, 1888. 
[4] M. Sauzet, « De la responsabilité des patrons envers les ouvriers », Revue critique de législation et de jurisprudence, 1883, p. 596-640 and 677-704.

[5] R. Saleilles, Les accidents du travail et la responsabilité civile. Essai d'une théorie objective de la responsabilité délictuelle, Paris, Rousseau, 1897.

[6] L. Josserand, La responsabilité du fait des choses inanimés, Paris, Rousseau, 1897.

[7] F. Ewald, L'État providence, Paris, 1986.

[8] These figures are based on my $\mathrm{PhD}$ research performed between 2006 and 2010. B. Debaenst, Een proces van bloed, zweet en tranen! Juridisering van arbeidsongevallen in de negentiende eeuw in België, Brussels, 2011 ; see also : B. Debaenst, « A study on juridification. The case of industrial accidents in nineteenth century Belgium », The Legal History Review, 2013, p. 247-273. The studied archives are : State Archives Mons, Civil court of Mons, numbers 89-124 and 196-204. I will refer to the date of the judgment. These judgments can easily be retraced in the judgments books, which are chronological.

[9] Article 1382 : «Any act whatever of man, which causes damage to another, obliges the one by whose fault it occurred, to compensate it ».

[10] Civil court of Mons, 10 July 1900.

[11] Civil court of Mons, 16 November 1901.

[12] « engin absolument défectueux, manquant complètement de stabilité et surtout manquant de protection sur les couteaux $»$.

[13] Civil court of Mons, 3 March 1900.

[14] Civil court of Mons, 28 July 1899.

[15] They also pointed out that there were no legal provisions on shoring or the way it had to be done, leaving the way of exploitation entirely to the defendant.

[16] Civil court of Mons, 23 February 1900.

[17] Civil court of Mons, 5 July 1900.

[18] Civil court of Mons, 28 January 1899.

[19] Civil court of Mons, 4 July 1886 ; 31 March 1892 ; 3 July 1896 ; 17 July 1896 ; 9

October 1902 ; 5 February 1903 ; 4 April 1903 ; 28 January 1904 ; 8 April 1904.

[20] Civil court of Mons, 2 May 1895 ; 3 March 1900.

[21] Civil court of Mons, 28 November 1895 ; 17 July 1896.

[22] To give only two examples : Emilia Lansman was the victim of a lethal accident in the underground transport on 15 July 1896. She died three days later. Civil court of Mons, 28 
January 1899 ; Jean-Joseph Peeters was the victim of a similar accident on 24 October 1896. He died on 14 November 1896. Civil court of Mons, 28 January 1899.

[23] Civil court of Mons, 20 April 1901.

[24] «Que le défendeur emploie habituellement des ouvriers inhabiles, inexpérimentés et sans aptitudes aucunes et que par sa propre faute, à maintes reprises, plusieurs ouvriers ont été blessé plus ou moins grièvement dans le courant de l'année 1900 et ont été, soit transportés à l’hôpital, soit soignés par le docteur Carlier ». Civil court of Mons, 20 April 1901.

[25] F. Loriaux, Enfants-machines. Histoire du travail des enfants en Belgique aux XIX ${ }^{e}$ et $X X^{e}$ siècles, Brussels, 2000 ; M. Rahikainien, Centuries of Child Labour. European Experiences from the Seventeenth to the Twentieth Century, Hampshire, 2004.

[26] Civil court of Mons, 29 June 1889.

[27] This was also the case in the civil trial dealing with the deadly accident of Hilaire Dubois on 6 February 1890. In their judgment of 29 June 1893 the judges wrote that the young age of Dubois had no causal link with the accident. After all, the explosion had not only killed Dubois, but also older miners. Civil court of Mons, 29 June 1893.

[28] «Que l'âge des victimes est indifférent en pareil cas et que d'ailleurs tous les ouvriers travaillant dans cette partie de la mine, jeunes et vieux, ont été atteint par le feu ».

[29] «Que si, en général, les enfants travaillant dans les établissements industriels doivent être soumis à une surveillance plus grande que les autres ouvriers, c'est afin de les protéger contre leurs propres imprudences ou contre les accidents qui seraient le résultat de leur inexpérience ».

[30] In a judgment dated on 14 March 1903 the Mons judges formulated it as follows : « Attendu que le patron est tenu de protéger les ouvriers contre leur propre imprévoyance ou leur imprudence surtout lorsque, comme dans l'espèce, ces ouvriers sont jeunes ». Civil court of Mons, 14 March 1903.

[31] Civil court of Mons, 30 June 1883.

[32] Civil court of Mons, 3 August 1883.

[33] Civil court of Mons, 28 January 1899.

[34] Civil court of Mons, 10 February 1900.

[35] Civil court of Mons, 8 July 1892.

[36] « Attendu que les demandeurs avaient été admis à prouver certains faits, que s'ils avaient été vérifiés auraient établi que les installations de la société défenderesse étaient dangereuses et que leur fils était chargé d'un travail trop périlleux eu égard de son âge. Attendu qu'ils ont atteint cette preuve ». 
[37] «Que, dès lors le danger devait grandir pour un enfant de l'âge de François Crombois qui n'avait ni la force, ni l'expérience d'un adulte ».

[38] Civil court of Mons, 30 November 1893.

[39] « À moins d'autorisation spéciale, le personnel se rend à son travail et en revient par la voie habituelle, sans s'attarder, sans monter dans les wagonnets, sans se rendre dans un chantier où il n’est pas appelé par son travail ». Civil court of Mons, 29 July 1899.

[40] Civil court of Mons, 12 May 1900.

[41] Art. 1384, 1st Civil Code : «A person is liable not only for the damages he causes by his own act, but also for that which is caused by the acts of persons for whom he is responsible, or by things which are in his custody ».

[42] «[...] l'accident est dû au mauvais fonctionnement du frein et à la disposition défectueuse de l'appareil ». Civil court of Mons, 8 May 1901.

[43] « Attendu qu'il est aujourd'hui de jurisprudence quasi constante que l'article $1384 \mathrm{du}$ code civil ne permet pas de réputer responsable, de plein droit, du dommage causé par le fait d'une chose inanimée, le propriétaire de cette chose ou celui qui en a la garde ». Civil court of Mons, 8 May 1901.

[44] Another example of this can be found in a judgment of 9 October 1902 : «Attendu que se basant sur ce que son action est intentée par application de l'article 1384 du Code civil, qui présume que le propriétaire de la chose est en faute, et sur ce que la défenderesse se borne à dénier les faits articulés sans conclure à établir l'absence de toute faute dans son chef, la demanderesse soutient à tort qu'elle se trouve par la même déchargée de toute preuve, et que la responsabilité de la société en tout état de cause est engagée ». Civil court of Mons, 9 October 1902.

[45] Cassation, 26 May 1904, Pasinomie [belge] 1904, I, 246.

[46] Art. 1384, Civil Code : «A person is responsible not only for the injury which is caused by his own act, but also for that which is caused by the act of persons for whom he is bound to answer, or by things which he has under his care. [...] masters and trustees, for the injury caused by their servants and managers in the functions in which they have employed them ».

[47] « Attendu que l'obligation que l'article 1384 du code civil impose aux maîtres et aux commettants de répondre du dommage causé par leurs domestiques et préposés, est basée sur une présomption légale de faute résultant de la négligence ou du défaut de surveillance de ces personnes ». Civil court of Mons, 15 January 1875.

[48] Civil court of Mons, 10 May 1883.

[49] «Les entrepreneurs sont responsables de la visite des câbles et en général des engins d'extraction qui leur sont confiés ; ils devront demander leur remplacement aussitôt qu'ils ne leur inspireront plus assez de confiance. Par contre, en cas d'accident, les entrepreneurs s'engagent à renoncer à toute action civile envers la société ». 
[50] Civil court of Mons, 21 February 1891.

[51] The outcome of this trial is unknown, as there was only an interlocutory judgment and no final judgment.

[52] «pour que Dubois puisse être considéré comme préposé de la société, il faudrait que celle-ci eût exercé sur lui une véritable autorité, qu'elle lui eût imposé une direction en se réservant de lui donner des ordres sur le mode d'exécution du travail entrepris, ce qui n'est pas le cas de l'espèce ».

[53] Civil court of Mons, 27 April 1901.

[54] « Pour que Mest puisse être considéré comme le préposé de la Société, il faudrait que celle-ci eût exercé sur lui une véritable autorité ; qu'elle se fut réservé le droit de lui donner des ordres quant aux modes d'exécution de l'ouvrage ».

[55] Civil court of Mons, 14 November 1885.

[56] « Cet entrepreneur n'est en réalité qu'un intermédiaire pour le règlement de salaire de fournir avec lequel il travaille et pour faciliter l'organisation du travail d'exploitation ».

[57] Article 1385, Civil Code : «The owner of an animal, or who makes use of it while it is in his employment, is responsible for the injury which the animal has occasioned, whether the animal were in his custody, or whether it had strayed or escaped ».

[58] Civil court of Mons, 11 January 1890.

[59] Civil court of Mons, 23 April 1891.

[60] Article 1386, Civil Code : «The proprietor of a building is responsible for the injury caused by its fall, when it has happened in consequence of the want of necessary repairs or from defect in its construction ».

[61] Civil court of Mons, 28 January 1897.

[62] C. Sainctelette, De la responsabilité et de la garantie (accidents de transport et de travail), Brussels, Bruylant, 1884 ; For an analysis of this theory, see : B. Debaenst, « A study on juridification. The case of industrial accidents in nineteenth century Belgium », The Legal History Review, 2013, p. 247-273.

[63] Civil court of Mons, 14 November 1885.

[64] «[...] par cela seul que cette société employait comme ouvrier son fils, le sieur Casimir Blase, elle doit répondre de tout dommage que ce dernier aurais souffert par suite ou à l'occasion de son travail ».

[65] « [...] en l'absence de stipulations formelles à cet egard garantissant la sûreté et la conservation des ouvriers ». 
[66] Civil court of Mons : 4 and 5 February, 30 April, 4 July, 6 August and 12 November 1886 ; 15 January, 28 May and 24 November 1887 ; 14 April, 1 May and 23 June 1888.

[67] M. Demeur, Le risque professionnel. Traité théorique et pratique de la loi du 24 décembre 1903 sur la réparation des dommages résultant des accidents du travail, Brussels, Larcier, 1908.

[68] For my $\mathrm{PhD}$ research, I studied 350 criminal files with workplace accidents in the period 1880-1904. State archives Mons, Criminal court, numbers 488-648 (judged cases 1880-1903) and the series «non lieu » between 1880-1903 (at the moment of consultation, this series was not numbered, but only chronological indicated). Further I will refer to the place and date of the accident.

[69] Article 418 : «Est coupable d'homicide ou de lésions involontaires, celui qui a causé le mal par défaut de prévoyance ou de précaution, mais sans intention d'attenter à la personne d'autrui »; Article 419 : «Quiconque aura involontairement causé la mort d'une personne sera puni d'un emprisonnement de trois mois à deux ans et d'une amende de cinquante francs à mille francs ». Article $420:$ "S'il n'est résulté du défaut de prévoyance ou de précaution que des coups ou des blessures, le coupable sera puni d'un emprisonnement de huit jours à deux mois et une amende de cinquante francs à cinq cents francs, ou d'une de ces peines seulement ». J.-S.-G. Nypels, Le Code pénal belge interprété principalement au point de vue de la pratique, Brussels, 1898, III, p. 112-119 ; G. Beltjens, Encyclopédie du droit criminel belge, Brussels, 1901, p. 506-512.

[70] « [...] en vice d'apprécier le fondement d'une action civile éventuelle des héritiers de la victime ». Haine-Saint-Paul, 12 décembre 1898. « Je suis chargé par le père, de rechercher la responsabilité civile dans cette affaire, et à cet effet, je vous prie de m'autoriser à prendre connaissance et au besoin copie du dossier relatif à cet accident »; Obourg, 29 juin 1898. « Le père de la victime [...] me prie de rechercher si la responsabilité civile de la carrière n'est pas engagée »; Maffles, 23 December 1897. «Je me permets de vous adresser cette demande, à l'effet de pouvoir me prononcer sur l'opportunité d'une action en responsabilité qui lui permettraient d'exercer des poursuites répressives. J'ose espérer que Monsieur le Procureur Général, voudra bien accéder à la demande, que j'adresse dans l'intérêt de la Justice et de la Verité »; Dour, 4 avril 1898. «Je suis chargé par son père d'en amener la question de savoir si une action peut être efficacement intentée à ladite société : il prétend, en effet, que la mort de son fils est le résultat d'un défaut de précaution ». Quaregnon, 20 May 1897. «La famille du dit sieur Laurysse me charge de réclamer éventuellement la réparation civile du préjudice qu'elle a subie du chef de ce mort »; Élouges, 9 October 1895. "Allard laisse une veuve et de jeunes enfants ; je suis chargé par la veuve de rechercher si la société n'est pas responsable des suites de l'accident, et de lui intenter, s'il échet, un procès ». Jemappes, 24 December 1893.

[71] « Si la responsabilité pénale des agents de l'usine n'est pas engagée, la responsabilité civile peut l'être »; La Louvière, 30 October 1899.

[72] « Je suis chargé des intérêts de la famille du défunt et je serais relativement éclairé sur le fondement de la demande en dommages-intérêts par l'examen des dossiers d'instruction »; La Louvière, 5 April 1899. 
[73] « Il m'est indispensable de connaître les dépositions recueillis par les magistrats instructeurs pour pouvoir défendre les intérêts qui me sont confiés »; Écaussines-d'Enghien, 30 August 1899.

[74] « Nonobstant, la Société vient d'être actionnée en dommages intérêts, à raison de cet accident. J'ai l'honneur de vous prier, monsieur le procureur général, de vouloir bien m'autoriser à me faire délivrer la copie du dossier, afin que je puisse répondre à l'action »; Dour, 4 April 1898. «C'est pour être en mesure de répondre à cette action que l'autorisation préindiqué est sollicitée »; Haine-Saint-Paul, 12 August 1897. «Il importe à mon client de produire à l'appui de ses moyens de défense les pièces du dossier de l'instruction dont je viens de parler »; Cuesmes, 18 March 1897. «L'intérêt de mon client, comme celui de la justice, étant de connaître les faits révélés devant le magistrat instructeur, je me permets, monsieur le procureur général, de venir vous demander, pour mon client, l'autorisation de prendre connaissance, au greffe du Tribunal de Mons, le dossier de cette affaire, comme aussi de retirer copie de toutes pièces, et même, s'il y a lieu, une expédition des dites pièces $»$; Jemappes, 14 January 1890.

[75] They often used standard expressions. Henry Sainctelette for example used the following model : [plaintiff] intents to start a civil trial against [defendant] because of [description of the damages - injuries or death], place and time. He ended his request with the standard phrase that his client had the greatest interest to study and copy the criminal file. "Celle-ci a le plus grand intérêt à prendre communication et à se faire délivrer copie du dossier de l'instruction à laquelle l'accident a donné lieu. Au nom de ma cliente, je vous prie de m'y autoriser ».

[76] «D'après ce qui m'a été dit au parquet de Mons je dois être muni d'une autorisation de votre part pour pouvoir consulter ce dossier ». Hornu, 9 August 1891.

[77] « L'accident survenu au sieur Jules Urbain, de Frameries, ayant donné lieu à une instruction qui n'est pas encore clôturée, M. le Procureur Général me charge de vous faire savoir qu'il ne peut actuellement statuer sur la demande de communication du dossier que vous lui avez adressez à la même date ». Strépy, 11 April 1899.

[78] «Attendu que cette preuve ne peut être considérée à l'égard de la société défenderesse comme résultant des pièces des instructions tant administrative qu'en matière répressive qui ont été faites en suite de l'accident, ladite société ayant été entièrement étrangère, et les explications qu'elle fournit sur les faits posés par les demandeurs et dont elle sera admise à fournir la preuve, dans l'ordre de la preuve contraire, suffisant à elles seules pour détruire les inductions que les demandeurs prétendent faire résulter de ces instructions ». Civil court of Mons, 12 February 1876.

[79] Civil court of Mons, 18 March 1896.

[80] « une longue, complète et minutieuse instruction ».

[81] «Que des lors, en présence du résultat des enquêtes administrative et judiciaire, l'expertise sollicitée subsidiairement par le demandeur serait inutile et frustratoire ». Civil court of Mons, 16 July 1903. 
[82] « Attendu que l'accident du 16 december 1890 a donné lieu à une information tant de la part du parquet que de la part de l'administration des mines ». Civil court of Mons, 13 January 1894.

[83] «Attendu que dans l'état de la cause, et en présence des éléments contradictoires qu'elle révèle, des avis différents, émis pourtant par des hommes d'une haute compétence en la matière, il n'est pas possible pour le tribunal de décider, sans recourir aux lumières de spécialistes, si ces faits engagent la responsabilité de la société défenderesse ».

[84] Civil court of Mons, 8 December 1892.

[85] Article 303 of the Judicial Code prescribed the appointment of three experts : « L'expertise ne pourra se faire que par trois experts, à moins que les parties ne consentent qu'il soit procédé par un seul ». In this case the experts were Bruno Lebrun, industrialist from Nimy, Charles Prévot, engineer from Boussu and Julien Weiler, engineer from Moranwelz.

[86] Civil court of Mons, 27 June 1894.

[87] « dans les conditions rapportées au procès-verbal de l'accident la manoeuvre imposée au jeune Née était extrêmement périlleuse ».

[88] Civil court of Mons, 12 July 1894.

[89] Civil court of Mons, 21 June 1900 and 7 November 1902.

[90] «1) de dire quelles ont été et quelles seront les conséquences de l'accident [...] et notamment s'il n'en est pas résulté pour lui "une neurasthénie traumatique' [ou] “des lésions internes, une neurasthénie traumatique, des névralgies violentes et des vertiges continuels", 2) de dire si à raison de cette/ces affection(s), il n'est pas incapable de tout travail, 3) de dire si cet état n'est pas définitif et non susceptible d'amélioration ou de guérison dans l'avenir, 4) de dire s'il n'en résulte pas de vives souffrances et si la vie n'en est pas abrégée ».

[91] Civil court of Mons, 8 January 1892.

[92] Civil court of Mons, 6 July 1893.

[93] « [...] dire si les lésions sont définitives ou si une amélioration de la situation actuelle lui permettra, à une époque à indiquer par les experts, de reprendre son travail. Dans

l'affirmative, s'il pourra reprendre dans des conditions analogues à celles où il exerçait avant l'accident. Dans la négative quelle est, suivant eux, la proportion dans laquelle la capacité de travail du demandeur serait diminué ». Civil court of Mons, 13 January 1899.

[94] Civil court of Mons, 13 January 1899.

[95] Civil court of Mons, 24 July 1896.

[96] Civil court of Mons, 22 October 1896.

[97] Civil court of Mons, 17 April 1897. 
[98] Civil court of Mons, 20 March 1903.

[99] «1. Le demandeur réparait habituellement le triage et en cas d'absence, remplaçait le machiniste. Il connaissait parfaitement l'installation. »

[100] «4. l'accident est dû à l'imprudence de la victime qui a voulu remettre la courroie seule alors que d'après l'ordre établi, un autre était chargé de faire cette besogne avec l'aide du demandeur. » 